\title{
Thermal performance amelioration of flat plate solar collector of an indirect dryer
}

\author{
Koua Kamenan Blaise ${ }^{1,2 *}$, Koffi Ekoun Paul Magloire ${ }^{1}$, Gbaha Prosper ${ }^{1}$ \\ ${ }^{1}$ Institut National Polytechnique Félix Houphouët Boigny, UMRI 58, Laboratoire d'Energies nouvelles et Renouvelables, \\ B.P. 581 Yamoussoukro, Cote d'Ivoire \\ ${ }^{2}$ Université Félix Houphouët Boigny, UFR SSMT, Laboratoire d'Energie Solaire, 22 B.P. 582 Abidjan 22, Cote d'Ivoire
}

Corresponding Author Email: kbkoua@yahoo.com

https://doi.org/10.18280/mmep.050410

Received: 14 August 2018

Accepted: 26 November 2018

\section{Keywords:}

flat plate collector, baffles, thermal efficiency, temperatures

\begin{abstract}
Article presents an experimental investigation for the comparison of thermal performance of three different configurations flat plate solar collector. These flat plate solar collectors consist of glass cover and aluminium absorber plate which is painted with black paint. The edge and bottom surfaces are thermally insulated with a polystyrene layer for the first configuration, a polystyrene layer covered with a sheet of aluminium paper for the second one and a polystyrene layer covered with a sheet of aluminium paper and containing baffles for the third configuration. In this experiment, thermal efficiency of flat plate solar collector integrated with baffles was studied and compared with the two ordinary flat plate collectors. The results showed that integrating flat plate solar collector with baffles significantly increased the thermal efficiency of the system. It was noted that a mean thermal efficiency is $20.3 \%, 29.8 \%$ and $35.1 \%$ for the first, second and third configuration, respectively. The results show a maximum temperature rise of $23.5{ }^{\circ} \mathrm{C}$, $31.6^{\circ} \mathrm{C}$ and $34.6^{\circ} \mathrm{C}$ with respect to the inlet air temperature, for the first, second and third configuration, respectively. Baffles improve the thermal performance of the flat plate solar collector by increasing the outlet temperature.
\end{abstract}

\section{INTRODUCTION}

The flat plate solar collectors are special kind of heat exchangers that transfer heat energy from incident solar radiation to the working fluid. They perform three functions, absorbing solar radiation, converting it to heat energy, and transferring the energy to a working fluid passing through the collector duct [1]. The flat plate solar collectors are considered to be simple devices consisting of one transparent cover situated above an absorbing plate with the air flowing under absorber plate and thermal insulation which resists back and rear side heat losses. They are used to deliver heated air for space heating, crop drying, and similar applications requiring air at a low-to-medium temperature. However, the main drawback of flat plate solar collectors is the low heat transfer coefficient between the absorber plate and the working fluid due to poor thermal conductivity and low heat capacity of air [1-2].

In order to improve the thermal performance of the flat plate solar collector, several designs and different methods have been suggested to increase the rate of heat transfer between working fluid and absorber plate. Ramesh et al. [3] researched on solar air collectors with baffles to favour heat transfer. The researcher carried out a project concerning solar air collectors and various techniques to increase the heat transfer coefficient between the air and the absorber such as a fixation of small wings to the absorber, the manner in which the airflows in the absorber, the shape of the collector and those of it inlets and outlets. Kasra and Sabzpooshani [4] studied the thermal assessment of solar air heater by using fins and baffles. They have suggested three different cases to evaluate the performance of energy analysis. The results were found that fins and baffles are enhanced their efficiency considerably. Hakan et al. [5] studied the methods of performance and efficiency improvement of different collectors using energy and exergy analysis. They found that applying obstacles can improve efficiency in comparison to simple ones. Nowzari and Aldabbagh [6] investigated experimentally the thermal performances of single and counter flow solar air heaters with a normal cover and with quarter and half perforated covers. In this work, on two of the perforated covers, the holes were made in the first quarter at the top side of the covers. As for the other two covers, half of the cover area on the top side was perforated. Chabane et al. [7] presented the experimentally thermal performance of a single pass solar air heater with fins attached. Longitudinal fins were used on the underside of the absorber plate to increase the heat exchange and render the flow fluid in the channel uniform. The effects of mass flow rate of air on the outlet temperature, the heat transfer in the thickness of the solar collector and thermal efficiency were studied. Bakari [8] presented an experimental analysis for comparisons of conventional flat plate solar collectors and collectors integrated with different numbers of baffles. Heat transfer between absorber plate and drying air has been one of the major challenges in the design and operations of the indirect solar dryer systems. Aissaoui et al. [9] developed a mathematical model for simulating the influence of fins and baffles on the thermal performance behaviour of single pass solar air collector system working in forced convection. Due to the lack of theoretical work in the case of single pass solar air heaters having artificial roughness, they have proposed a 
theoretical model which consists of dividing the collector into several differential elements along the panel. Shemelin and Matuska [10] presented a theoretical analysis of flat plate solar collectors with a vacuum glazing. Different configurations of the collector have been investigated by a detailed theoretical model based on a combined external and internal energy balance of the absorber. Performance characteristics for vacuum flat plate collector alternatives have been derived. Jahed and Ajabshirchi [11] studied experimentally the effect of obstacles on efficiency of flat plate air solar collector. They show that the average temperature of the simple absorber plate collector was higher than the collector with obstacles, while the efficiency of the collector with obstacles was found to be higher than the simple collector's efficiency.

However, there are not enough works which are carried out on the thermal performance of flat plate solar collector integrating baffles and whose the thermal insulator is covered with a sheet of aluminium paper. Thus, the main objective of this study is to improve the thermal performance of flat plate solar collector using baffles mounted on the thermal insulator covered with an aluminium paper sheet. Also, the study focuses on the comparison of the thermal performance of three flat plate solar collectors' configurations, identical in design, fabrication, and operating under the same conditions. The flat plate solar collector considered to be a simple device consisting of one transparent cover situated above an absorbing plate with the air flowing under absorber plate.

\section{MARERIAL AND METHODS}

\subsection{Description of the flat plate solar collector}

The flat plate solar collector used in this study is the collector of an indirect solar dryer. The indirect solar dryer has been designed and constructed at the Laboratory of New and Renewable Energy at the Polytechnic Institute of Yamoussoukro, Côte d'Ivoire. As shown in Fig. 1, the indirect solar dryer consists mainly of a solar air collector system and a drying chamber containing tree rectangular trays of $95 \mathrm{~cm} \mathrm{x} 106 \mathrm{~cm}$ dimensions and a flux diffuser of 97 $\mathrm{cm} \times 106 \mathrm{~cm}$ dimensions. The flux diffuser is a performed surface through which the hot air arriving from the solar collector passes and exiting through the holes creates a uniformly distributed flow. The solar air collector system was used to produce thermal energy for drying. The solar air collector consists of glass cover and aluminium absorber plate which is painted with black paint in order to increase the absorption for the global solar radiation beam and diffuse light [12]. It is tilted to an angle of $7^{\circ}$ with respect to horizontal surface. The solar air collector has a useful collector area of $2 \mathrm{~m}^{2}$, and a channel size of $2.5 \mathrm{~cm}$ high. The edge and bottom surfaces are thermally insulated with polystyrene of thermal conductivity of $0.036 \mathrm{~W} / \mathrm{mK}$.

In order to improve the thermal performance of the flat plate solar collector, three configurations identical in design and fabrication were realized.

- First configuration (Fig 2.a): The edge and bottom surfaces of flat plate solar collector are thermally insulated with a $5 \mathrm{~cm}$ thick polystyrene layer.

- Second configuration (Fig 2.b): The edge and bottom surfaces of flat plate solar collector are thermally insulated with a $5 \mathrm{~cm}$ thick polystyrene layer covered with a sheet of aluminium paper.

- Third configuration (Fig 2.c): The edge and bottom surfaces of flat plate solar collector are thermally insulated with a $5 \mathrm{~cm}$ thick polystyrene layer covered with a sheet of aluminium paper on which baffles are mounted. The baffles have a length of $50 \mathrm{~cm}$.

Baffles disrupt the flow of fluids and can be used for changing the flow direction at any point. The baffles provide an additional heat transfer surface area and promote air turbulence in the collector. The presence of baffles causes the air flow to separate, reattach and create a reverse flow which increasing the heat washing action. The main concept of integrating collector with baffles is to reduce dead zones and increase heat transfer area [8].

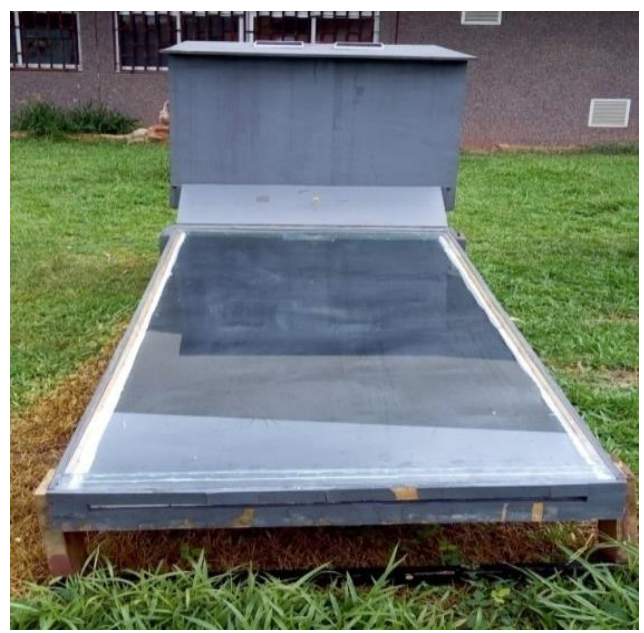

Figure 1. Picture view of indirect solar dryer

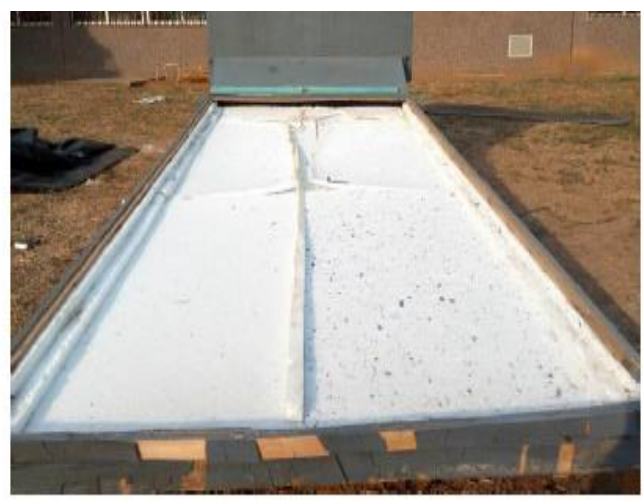

(a)

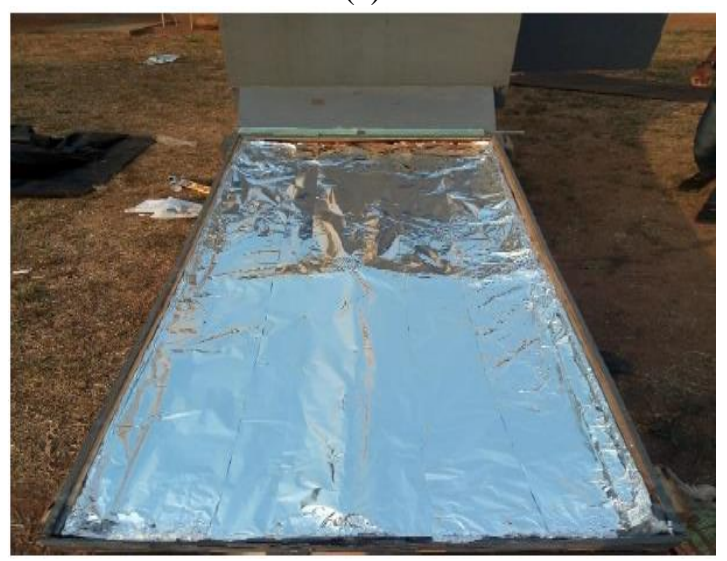

(b) 


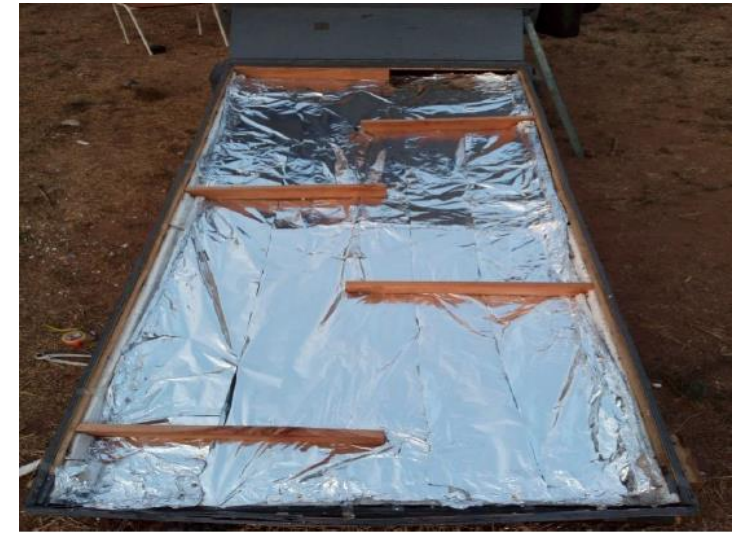

(c)

Figure 2. Configurations of flat plate solar collector

\subsection{Instrumentation}

During the experimental process, the total incident solar radiation was measured using a pyranometer Kipp and Zonen CM 10. This meter was placed adjacent to the tranparent cover, at the same plane. Type K thermocouples constituted by the couple of conductor (Nickel 10\% Chrome (+)/Nickel $5 \%$ Aluminum (-)) were used for measurement of the temperatures inside the flat plate solar collector. The data acquisition was carried out manually using a Voltcraft PL120-T2 digital thermometer. Indeed, four thermocouples were positioned evenly, on the top surface of the absorber plates, at identical positions along the direction of flow, for the three configurations of collectors. Inlet and outlet air temperatures were measured by two well-insulated thermocouples, while a thermocouple placed midway in the air passage section measures the air temperature in the collector.

\subsection{Basic theory}

The flat plate solar collectors are being used for thermal conversion to raise the temperature of fluid flowing through the collector. Conversion of solar radiations to thermal energy is mainly due to heat transfer coefficient between absorber plate and the fluid flowing in the collector. The energy gained by the flat plate solar collector during the time of the experiment can be expressed as [13-15]:

$q_{u}=\int_{0}^{t} \dot{m} A_{c}\left(H_{o}-H_{i}\right) d t$

where $\dot{m}$ is the flow rate of air per unit area of the absorber $\left(\mathrm{kg} / \mathrm{sm}^{2}\right), \mathrm{A}_{\mathrm{c}}$ is the surface of the flat plate solar collector $\left(\mathrm{m}^{2}\right), \mathrm{H}_{0}$ and $\mathrm{H}_{\mathrm{i}}$ are the outlet and inlet enthalpy variation of the flat plate solar collector $(\mathrm{kJ} / \mathrm{kg})$, respectively and $\mathrm{t}$ is the time.

The thermal efficiency of the flat plate solar collector can be calculated as:

$\eta=\frac{q_{u}}{G}=\frac{\int_{0}^{t} \dot{m} A_{c}\left(H_{0}-H_{i}\right) d t}{3.6 \int_{0}^{t} A_{c} I_{t} d t}$

The surface of the flat plate solar collector being constant, the Eq. (2) can be rewritten as:

$$
\eta=\frac{\int_{0}^{t} \dot{m}\left(H_{0}-H_{i}\right) d t}{3.6 \int_{0}^{t} I_{t} d t}
$$

where $\mathrm{G}$ is the total solar energy received by the flat plate solar collector during the time of the experiment $(\mathrm{kJ}), \mathrm{I}_{\mathrm{t}}$ is the instantaneous solar radiation incident on the tilted surface of the flat plate solar collector $\left(\mathrm{W} / \mathrm{m}^{2}\right)$.

The rate of useful energy of the flat plate solar collector can be also expressed by using overall heat loss coefficient and the collector temperature as $[8,16]$ :

$$
q_{u}=q_{\text {in }}-q_{\text {loss }}=A_{c}\left[(\tau \alpha) I_{t}-U_{L}\left(T_{c}-T_{a m}\right)\right]
$$

where $\mathrm{q}_{\text {in }}$ and $\mathrm{q}_{\text {loss }}$ are the total energy received and lost by the flat plate solar collector, respectively, $\mathrm{U}_{\mathrm{L}}$ is the overall thermal loss coefficient of the flat plate solar collector, $\mathrm{T}_{\mathrm{am}}$ is the ambient temperature, $T_{c}$ is the absorber temperature, $\alpha$ is the solar absorptance of the absorber and $\tau$ is the solar transmittance of the transparent cover.

Since it is difficult to define the absorber average temperature $\left(\mathrm{T}_{\mathrm{c}}\right)$, it is convenient to define the collector heat removal factor $\left(F_{R}\right)$ that relates the actual useful energy gained of a flat plate solar collector to the useful gained by the working fluid. This collector heat removal factor $\left(F_{R}\right)$ is expressed by $[8,16]$ :

$$
F_{R}=\frac{\dot{m} A_{c} C_{p a}\left(T_{0}-T_{i}\right)}{A_{c}\left[(\tau \alpha) I_{t}-U_{L}\left(T_{i}-T_{a m}\right)\right]}=\frac{\dot{m} C_{p a}\left(T_{0}-T_{i}\right)}{(\tau \alpha) I_{t}-U_{L}\left(T_{i}-T_{a m}\right)}
$$

The instantaneous thermal efficiency of the flat plate solar collector is obtained by dividing the useful energy gained by the working fluid by the incident radiation.

$$
\eta_{\text {inst }}=\frac{q_{u}}{A_{c} I_{t}}=\dot{m} C_{p a} \frac{\left(T_{0}-T_{i}\right)}{I_{t}}=F_{R}\left[(\tau \alpha)-U_{L} \frac{\left(T_{i}-T_{a m}\right)}{I_{t}}\right]
$$

Plot between instantaneous efficiency of the solar collector and temperature rise parameters $\left(T_{i}-T_{a m}\right) / I_{t}$ is represented by straight line if overall loss coefficient $U_{L}$, heat removal factor $F_{R}$ and transmittance absorptance product $(\tau \alpha)$ are constants. The y-intercept and the slope of the straight line (represented by Eq. (6)) yields the values of $F_{R}(\tau \alpha)$ and $\mathrm{F}_{\mathrm{R}} \mathrm{U}_{\mathrm{L}}$, respectively.

\section{RESULTS AND DISCUSSION}

Performance and testing of a flat plate solar collector of an indirect dryer were carried out in Yamoussoukro at $6.58^{\circ} \mathrm{N}$ latitude and throughout a sunny day. The daily irradiation of this sunny day is $6073.1 \mathrm{Wh} / \mathrm{m}^{2}$. During the experiments, the following measurements were carried out on daily basis: global flux received by the flat plate solar collector, total daily irradiation, ambient temperature and temperatures in various points of the three configurations of the system studied. These basic physical parameters are reported in order to determine and compare the thermal performance of the 
three configurations of the flat plate solar collector.

Figure 3 shows that the ambient temperature $\left(\mathrm{T}_{\mathrm{am}}\right)$ and the instantaneous solar flux increase gradually to reach a maximum value before decreasing. The recorded maximum ambient temperature is $39.1{ }^{\circ} \mathrm{C}$ at $12 \mathrm{~h} 20 \mathrm{~min}$ with a maximum instantaneous solar flux of $1075 \mathrm{~W} / \mathrm{m}^{2}$. In general, the ambient temperature and the instantaneous solar flux fluctuate in the same direction. They reach their maximum and minimum value at the same time of day.

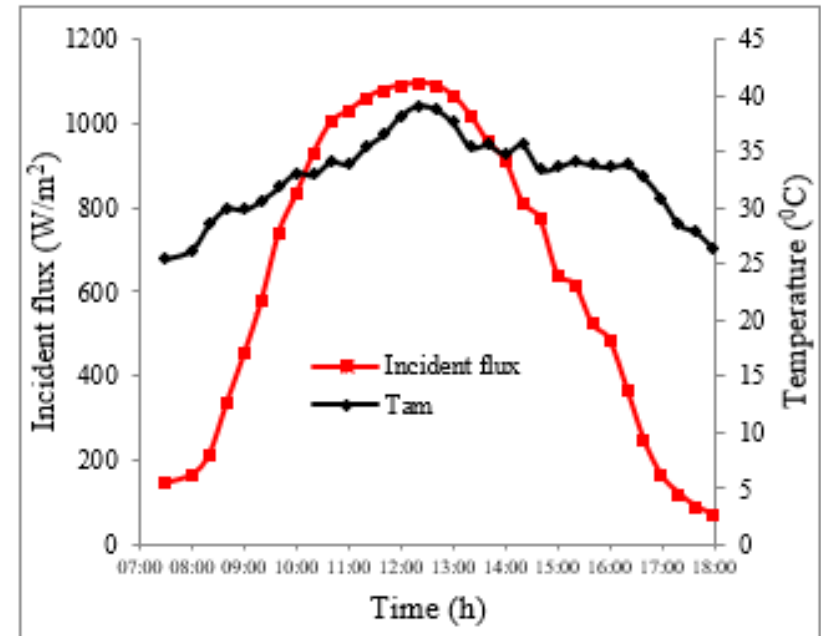

Figure 3. Variation of the ambient temperature and instantaneous solar flux versus time

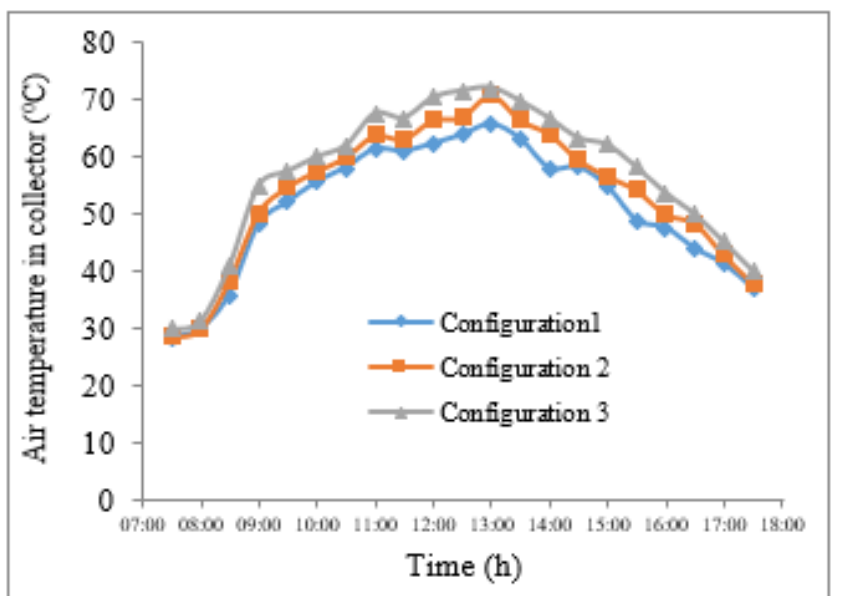

Figure 4. Variation of the air temperature in flat plate solar collector versus time

Figure 4 shows the variation of the air temperature in the flat plate solar collector for the three configurations. This figure 4 clearly shows that the air temperature in the flat plate solar collector for the three configurations is varying with respect to the instantaneous solar flux as reported by Vijayan and Arjunan [17]. The maximum value of the air temperature in the flat plate solar collector is observed as $65.7^{\circ} \mathrm{C}, 70.8^{\circ} \mathrm{C}$ and $72{ }^{\circ} \mathrm{C}$ for the first, second and third configuration, respectively during the peak sunshine hours, around $13 \mathrm{~h}$. As it can be seen in this figure 4 , the highest air temperature in the flat plate solar collector was achieved by the third configuration of the flat plate solar collector, whereas the lowest value was obtained from the first configuration.

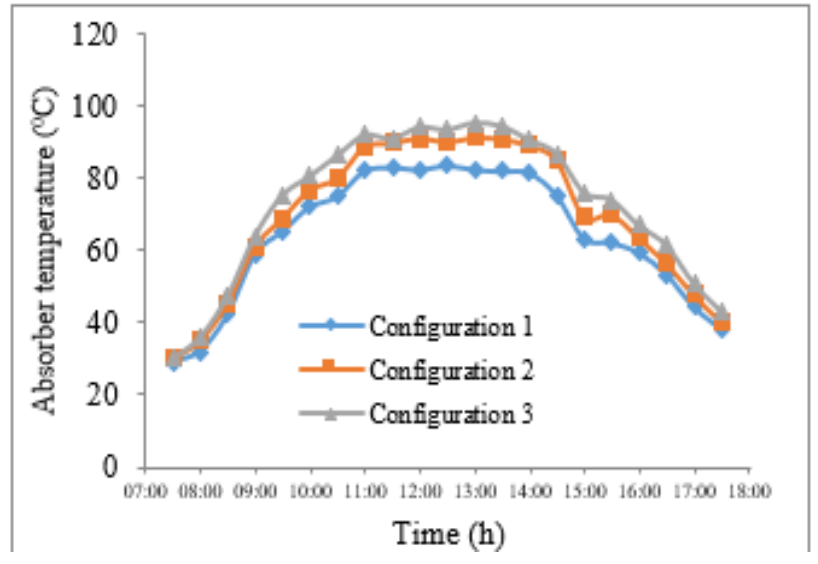

Figure 5. Variation of absorber temperature versus time

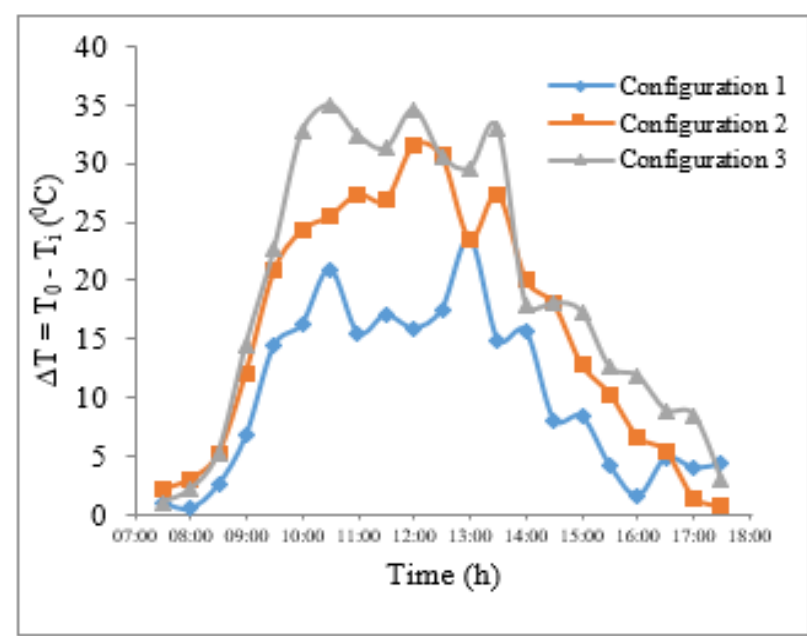

Figure 6. Variation of air temperature differnce between the outlet and inlet versus time

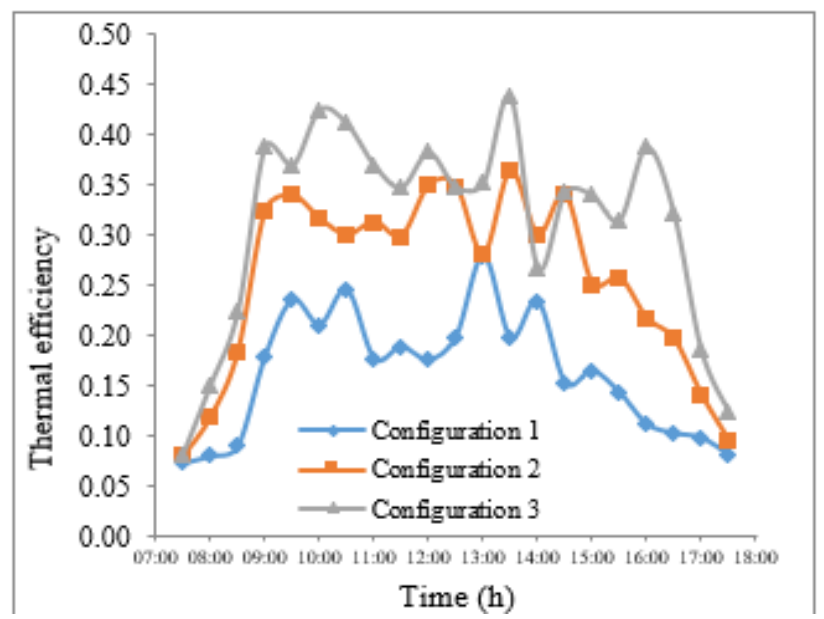

Figure 7. Variation of thermal efficiency versus time

Figure 5 presents the variation of the absorber temperature for the three configurations of the flat plate solar collector, according to the time. It is noticed that the three curves have the same profile. This profile is similar to that of the instantaneous solar flux and that the variations in absorber temperatures are very sensitive with respect to its disturbances as reported by Vijayan and Arjunan [17] and Aoues et al. [18]. The maximum value of the absorber 
temperature is observed as $83.6{ }^{\circ} \mathrm{C}, 91.3{ }^{\circ} \mathrm{C}$ and $95.4{ }^{\circ} \mathrm{C}$ for the first, second and third configuration of the flat plate solar collector, respectively during the peak sunshine hours, around $13 \mathrm{~h}$. The highest absorber temperature was achieved by the third configuration of the flat plate solar collector, whereas the lowest value was obtained from the first configuration.

Figure 6 shows the variation of the air temperature difference between the outlet and inlet, $\Delta \mathrm{T}=\mathrm{T}_{0}-\mathrm{T}_{\mathrm{i}}$, versus the time for the three configurations of the flat plate solar collector. It is found that the third configuration of the flat plate solar collector reaches a higher $\Delta \mathrm{T}$ than the two others configurations. The maximum temperature difference obtained was $23.5{ }^{\circ} \mathrm{C}, 31.6{ }^{\circ} \mathrm{C}$ and $34.6{ }^{\circ} \mathrm{C}$ for the first, second and third configuration, respectively at $12 \mathrm{~h}$ and air mass flow rate of $0.024 \mathrm{~kg} / \mathrm{s}$. This can be explained by the fact that the baffles forced air to take longer meandering trajectory than the normal length of the flat plate solar collector. The air passes onto the warm wall of the absorber surface which resulted in good heat transfer and a considerable increase in outlet temperature [8]. The outlet temperature is the most important in the calculation of the flat plate solar collector thermal efficiency. Increasing of the outlet temperature leads to increasing of thermal efficiency of the flat plate solar collector [19-20]. Similar results exist in the literature. Aldabbagh et al. [21] investigated a single-pass solar air heater with 10 wire mesh layers in a channel with a high of $10 \mathrm{~cm}$, and the maximum value of $\Delta \mathrm{T}$ obtained was $27{ }^{\circ} \mathrm{C}$ at air mass flow rate of $0.012 \mathrm{~kg} / \mathrm{s}$. Nowzari and Aldabbagh [6] investigated a counter-flow collector with a normal plexiglas cover, and the maximum value of $\Delta \mathrm{T}$ obtained was $34.8{ }^{\circ} \mathrm{C}$ at air mass flow rate of $0.011 \mathrm{~kg} / \mathrm{s}$.

Figure 7 illustrates the variation of the thermal efficiency with the time for the three configurations of the flat plate solar collector. It can be noted that from this figure 7 that the thermal efficiency of the third configuration is higher than those of the two others configurations. The average thermal efficiency determined using Eq. (3) was $20.3 \%, 29.8 \%$ and $35.1 \%$ for the first, second and third configuration of the flat plate solar collector, respectively at air mass flow rate of $0.012 \mathrm{~kg} / \mathrm{s}$. Similar results exist in literature. Indeed, Vijayan and Arjunan [17] studied the thermal performance of indirect forced convection solar dryer with the air mass flow rate of $0.058 \mathrm{~kg} / \mathrm{s}$, and the thermal efficiency of the collector is observed in the range of $20 \%$ to $32 \%$. Aissaoui et al. [22] presented an experimental and theoretical analysis on thermal performance of the flat plate solar air collector, and the thermal efficiency of this collector is observed in the range of $22.5 \%$ to $40 \%$ at air mass flow rate of $0.1324 \mathrm{~kg} / \mathrm{s}$. Bakari [8] studied the thermal efficiency of air flat plate solar collector with different numbers of baffles. He obtained a thermal efficiency between $28.9 \%$ and $33.7 \%$.

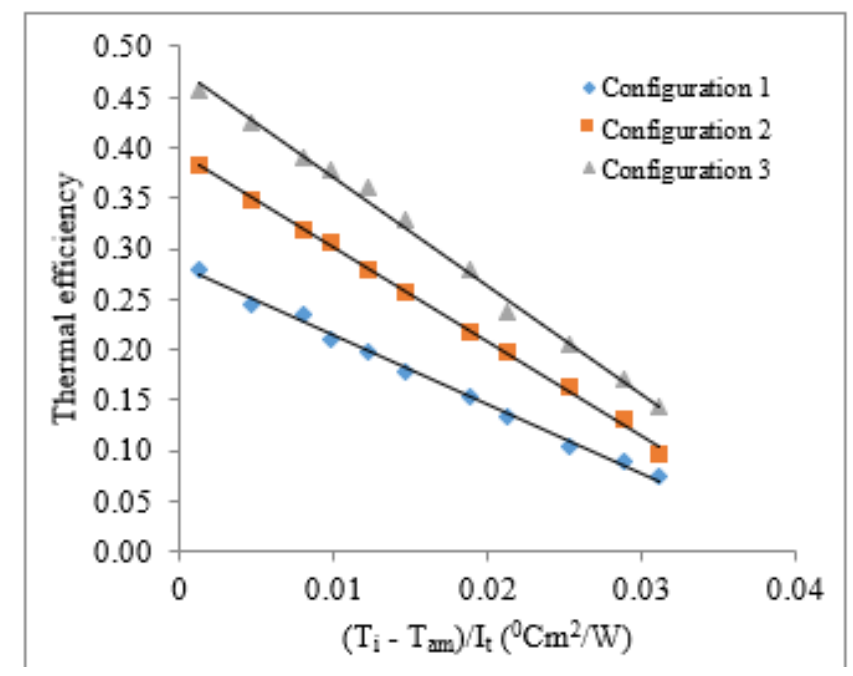

Figure 8. Variation of thermal efficiency versus $\left(T_{i}-T_{a m}\right) / I_{t}$

Table 1. Thermal efficiency equation and physical characteristics of flat plate solar collector

\begin{tabular}{ccccccc}
\hline Configurations & Thermal efficiency equation & $\mathrm{F}_{\mathrm{R}}(\tau \alpha)$ & $\mathrm{F}_{\mathrm{R}} \mathrm{U}_{\mathrm{L}}$ & $\mathrm{F}_{\mathrm{R}}$ & $\mathrm{U}_{\mathrm{L}}$ & $\mathrm{r}^{2}$ \\
\hline First & $\eta=0.282-6.848 \frac{T_{i}-T_{a m}}{I_{t}}$ & 0.282 & 6.848 & 0.363 & 18.865 & 0.994 \\
Second & $\eta=0.394-9.321 \frac{T_{i}-T_{a m}}{I_{t}}$ & 0.394 & 9.321 & 0.507 & 18.385 & 0.998 \\
Third & $\eta=0.478-10.730 \frac{T_{i}-T_{a m}}{I_{t}}$ & 0.478 & 10.730 & 0.615 & 17.447 & 0.995 \\
\hline
\end{tabular}

Therefore, it's clear that the thermal efficiency of the flat plate solar collector depends significantly on the air mass flow rate and the solar radiation. In addition, the introduction of baffles improves the thermal performance of the flat plate solar collector by the increase of the outlet temperature.

Figure 8 illustrates the variation of the instantaneous thermal efficiency versus $\left(\mathrm{T}_{\mathrm{i}}-\mathrm{T}_{\mathrm{am}}\right) / \mathrm{I}_{\mathrm{t}}$ for the three configurations of the flat plate solar collector. This figure 8 reveals that increasing the collector performance coefficient, $\left(\mathrm{T}_{\mathrm{i}}-\mathrm{T}_{\mathrm{am}}\right) / \mathrm{I}_{\mathrm{t}}$, leads to a decrease in the instantaneous thermal efficiency. The experimental values fitted into a straight line by the last square fitting method allow obtaining the thermal efficiency equations given in Table 1. A comparison of the collector heat removal factor values, $F_{R}$, shows that the third configuration of flat plate solar collector achieves a significant improvement in the thermal efficiency. The heat removal factor is a vital parameter in determining the thermal efficiency of a flat plate solar collector. As a main factor of thermal performance, $F_{R}$ represents the ratio of the actual heat transfer to the maximum yield of heat transfer.

\section{CONCLUSION}

In this research work, three different configurations of the flat plate solar collectors were tested and their thermal performance was compared. The following conclusions can be derived: 
The thermal efficiency of the flat plate solar collector depends significantly on the air mass flow rate and solar radiation.

The highest flat plate solar collector thermal efficiency and the rise of air temperature difference between outlet and inlet were achieved by the third configuration where the edge and bottom surfaces of flat plate solar collector are thermally insulated with a $5 \mathrm{~cm}$ thick polystyrene layer covered with a sheet of aluminium paper on which baffles are mounted.

The thermal efficiency values at the air mass flow rate of $0.024 \mathrm{~kg} / \mathrm{s}$ were $20.3 \%, 29.8 \%$ and $35.1 \%$ for the first, second and third configuration of flat plate solar collector, respectively.

It can be seen that baffles reduce air space channel situated between the insulator and the absorber and increase the friction with the contact surfaces all of which increases the thermal performance of flat plate solar collector.

\section{REFERENCES}

[1] Bakari R, Minja RJA, Njau KN. (2014). Effect of glass thickness on performance of flat plate solar collectors for fruits drying. Hindawi Journal of Energy Article. http://dx.doi.org/10.1155/2014/247287

[2] El-Sebaii AA, Aboul-Enein S, Ramadan MRI, Shalaby SM, Moharram BM. (2011). Thermal performance investigation of double pass-finned plate solar air heater. Applied Energy 88(5): 1727-1739. https://doi.org/10.1016/j.apenergy.2010.11.017

[3] Ramesh N, Paschapure M, Nippanikar N, Karigoudar S, Nataraj SJR, Badarinarayana K. (2016). Performance studies of sustainable solar dryer for drying agricultural products. Indian Journal of Science and Technology 9(45). https://doi.org/10.17485/ijst/2016/v9i45/104682

[4] Kasra M, Sabzpooshani M. (2014). Appraising the performance of a baffled solar air heater with external recycle. Energy Conversion and Management 88: 239350. https://doi.org/10.1016/j.enconman.2014.08.009

[5] Oztop Hakan F, Bayrak F, Hepbarsli A. (2013). Energetic and exergetic aspects of a solar air heating (solar collector) system. Renewable and Sustainable $\begin{array}{lll}\text { Energy } & \text { Review } & \text { 59-83. }\end{array}$ https://doi.org/10.1016/j.rser.2012.12.019

[6] Nowzari R, Aldabbagh LBY. (2017). Experimental study on a solar air heater with various perforated Covers. Sadhana 42(9): $1585-1593$ https://doi.org/10.1007/s12046-017-0711-z

[7] Chabane F, Moummia N, Benramache C. (2013). Experimental analysis on thermal performance of a solar air collector with longitudinal fins in a region of Biskra, Algeria. Journal of Power Technologies 93(1): $52-58$.

[8] Bakari R. (2018). Heat transfer optimization in air flat plate solar collectors integrated with Baffles. Journal of Power and Energy Engineering 6: 70-84. https://doi.org/10.4236/jpee.2018.61006

[9] Aissaouil F, Benmachiche AH, Brima A, Belloufi Y, Belkhiri M. (2017). Numerical study on thermal performance of a solar air collector with fins and baffles attached over the absorber plate. International Journal of Heat and Technology 35(2): 289-296. https://doi.org/10.18280/ijht.350209
[10] Shemelin V, Matuska T. (2017). Detailed modeling of flat plate solar collector with vacuum glazing. Hindawi International Journal of Photoenergy. https://doi.org/10.1155/2017/1587592

[11] Jahed SH, Ajabshirchi Y. (2014). Experimental study of the effect of obstacles on efficiency of flat plate air solar collector. ISESCO Journal of Science and Technology 10(18): 11-16.

[12] Wenceslas KY, Ghislain T. (2018). Experimental validation of exergy optimization of a flat-plate solar collector in a thermosyphon solar water heater. Arabian Journal for Science and Engineering. https://doi.org/10.1007/s13369-018-3227-x

[13] Singh S, Dhiman P. (2016). Thermal performance of double pass packed bed solar air heaters - A comprehension review. Renewable and Sustainable Energy Reviews 53: 1010-1031. https://doi.org/10.1016/j.rser.2015.09.058

[14] Nahar A, Hasanuzzaman M, Rahim NA. (2017). Numerical and experimental investigation on the performance of a photovoltaic thermal collector with parallel plate flow channel under different operating conditions in Malaysia. Solar Energy 144: 517-528. https://doi.org/10.1016/j.solener.2017.01.041

[15] Wanga W, Lib M, Hassanienb RHE, Wang Y, Yanga L. (2018). Thermal performance of indirect forced convection solar dryer and kinetics analysis of mango. Applied Thermal Engineering 134: 310-321. https://doi.org/10.1016/j.applthermaleng.2018.01.115

[16] Bolaji BO. (2011). Exergetic analysis of solar energy drying systems. Natural Resources 2: 92-97. https://doi.org/10.4236/nr.2011.22012

[17] Vijayan S, Arjunan TV. (2015). Performance study of an indirect forced convection solar dryer for potato. International Journal of Applied Engineering Research 10(50): 454-458.

[18] Aoues K, Moummi N, Zellouf M, Benchabane A. (2011) Thermal performance improvement of solar air flat plate collector: A theoretical analysis and an experimental study in Biskra, Algeria. International Journal of Ambient Energy 32(2): 95-102. https://doi.org/10.1080/01430750.2011.584469

[19] Sadaghiyani OK, Boubakran MS, Hassanzdeh A. (2018). Energy and exergy analysis of parabolic trough collectors. International Journal of Heat and Technology 36(1): 147-158. https://doi.org/10.18280/ijht.360120

[20] Benseddik A, Azzi A, Khanniche R, Allaf AK. (2018). Simulation study of solar air collector with offset strip fin absorber plate for drying agricultural products in a semi-arid climate. International Journal of Heat and $\begin{array}{lll}\text { Technology 36(2): 557-568. } & \text { 36 }\end{array}$ https://doi.org/10.18280/ijht.360219

[21] Aldabbagh LBY, Egelioglu F, Ilkan M. (2010). Single and double pass solar air heaters with wire mesh as packing bed. Energy 35(9): 3783-3787. https://doi.org/10.1016/j.energy.2010.05.028

[22] Aissaoui F, Benmachiche AH, Brima A, Bahloul D, Belloufi Y. (2016). Experimental and theoretical analysis on thermal performance of the flat plate solar air collector. International Journal of Heat and Technology 34(2): 213-220. https://doi.org/10.18280/ijht.340209 


\section{NOMENCLATURE}

$\mathrm{A}_{\mathrm{c}} \quad$ surface of the flat plate solar collector, $\mathrm{m}^{2}$

$\mathrm{C}_{\mathrm{p}} \quad$ Specific heat, $\mathrm{J}_{\mathrm{kg}} \mathrm{kg}^{-1} \cdot \mathrm{K}^{-1}$

$\mathrm{F}_{\mathrm{R}} \quad$ collector heat removal factor

G total solar energy received, $\mathrm{kJ}$

$\mathrm{H}$ enthalpy variation, $\mathrm{kJ}^{\mathrm{kg}} \mathrm{kg}^{-1}$

$\mathrm{I}_{\mathrm{t}} \quad$ instantaneous solar radiation incident, $\mathrm{W} . \mathrm{m}^{-2}$

$\dot{m} \quad$ flow rate of air per unit area, $\mathrm{kg} \cdot \mathrm{s}^{-1} \cdot \mathrm{m}^{-2}$

qin total energy received, $\mathrm{kJ}$

qloss total energy lost, $\mathrm{kJ}$

$\mathrm{qu}_{\mathrm{u}} \quad$ useful energy, $\mathrm{kJ}$

$\mathrm{T}$ temperature, ${ }^{\circ} \mathrm{C}$

$\mathrm{t}$ time, $\mathrm{s}$
$\mathrm{U}_{\mathrm{L}} \quad$ overall thermal loss coefficient, $\mathrm{W} \cdot \mathrm{m}^{-2} \cdot \mathrm{K}^{-1}$

\section{Greek symbols}

a solar absorptance of the absorber

$\eta \quad$ thermal efficiency

$\tau \quad$ solar transmittance of the transparent cover

\section{Subscripts}

am ambient

c absorber

i inlet

o outlet 